\title{
Determinants of Use of Information and Communication Technologies in Agriculture: The Case of Kenya Agricultural Commodity Exchange in Bungoma County, Kenya
}

\author{
Amos W. Wawire ${ }^{1,2}$, Sabina M. Wangia ${ }^{1} \&$ Julius J. Okello ${ }^{1}$ \\ ${ }^{1}$ Department of Agricultural Economics, College of Agriculture and Veterinary Sciences, University of Nairobi, \\ Kenya \\ ${ }^{2}$ Department of Agricultural Resource Economics and Extension, School of Agriculture \& Biotechnology, \\ Karatina University, Kenya \\ Correspondence: Amos Wawire, Department of Agricultural Resource Economics and Extension, School of \\ Agriculture \& Biotechnology, Karatina University, P.O. Box 1957-10101, Karatina, Kenya. Tel: \\ 254-720-282-813.E-mail: wanjamos@gmail.com
}

Received: August 12, $2016 \quad$ Accepted: January 10, $2017 \quad$ Online Published: February 15, 2017

doi:10.5539/jas.v9n3p128 URL: http://dx.doi.org/10.5539/jas.v9n3p128

This work was supported by a research grant from National Commission for science, Technology and Innovation (NACOSTI), formerly known as Kenya's National Council of Science \& Technology (NCST).

\begin{abstract}
Access to markets by Smallholder farmers has conventionally been constrained by lack of market information. Efforts to strengthen access of farmers to markets has triggered the mushrooming of several projects that embrace ICT tools in promoting access to competitive market information. Nevertheless, most farmers still lack access to accurate market information, such as existing commodity prices. This study examines the determinants of the use of ICT tools among smallholder farmers for agricultural transactions. The study uses Kenya Agricultural Commodity Exchange (KACE), one of the ICT-based marketing platform, as the case study. The objectives of the research are to determine the factors that influence access to agricultural information, and establishing factors that determine the intensity of use of ICT tools in accessing agricultural information. Survey was conducted among 136 smallholder farmers in Bungoma County. Both purposive, and multi-stage sampling were used to obtain the sample for this research. The study finds that several farmer characteristics, farm and capital endowment factors affect the use of ICT tools, particularly mobile phones. Gender, age, literacy level, affordability, perceived importance, mobile ownership and group membership were found to be significant in influencing the decision to use KACE ICT tools and the intensity of use of these tools for agricultural transaction activities. The study further recommends for policies that support the expansion of ICT projects, training on their applications and sensitization on the use of these platforms. The study suggests for policies to address gender disparities on access and use of ICT tools for agricultural transaction.
\end{abstract}

Keywords: information and communication technology, market, market information, Kenya Agricultural Commodity Exchange, ICT, mobile phones, smallholder famers, agricultural information, market access

\section{Introduction}

Agricultural information is a critical ingredient to improving small-scale agricultural production and linking farmers to profitable markets. This will translate to better rural livelihoods in terms of food security locally and regionally. Improved productivity in agriculture will be realized when farmers are linked to market information (Rogaly, Harriss-White, \& Bose, 1999). However, in most rural regions, the smallholder farmers and small-scale entrepreneurs are consistently incapacitated by lack of information on prevailing market prices before they travel to the market. This has been occasioned by poor communication facilities forcing farmers to often rely on middlemen who take advantage to exploit them. Poorly organized marketing activities coupled with inadequate marketing experience, and poor access to farm capital, have further exacerbated farmers' woes (Munyua, 2007). 
This scenario has necessitated the emergence of ICT-based marketing information systems especially in developing countries, which target small-scale producers. Some of these include and not limited to, the Kenya Agricultural Commodity Exchange (KACE) and DrumNet in Kenya; TradeNet in Ghana; Malawi Agricultural commodity Exchange in Malawi; Songhai Centre in Benin, and women of Uganda Network (WOUGNET) in Uganda (Ferris, Engoru, \& Kaganzi, 2008). Others include Govi Gnana Seva (DDEC) in Sri-Lanka; D-Net1's Community-based Technology Centre (CTC) and Grameenphone and Katalyst2's Grameenphone Community Information Centre GPCIC in Bangladesh (Dey, Prendergast, \& Newman, 2008). These initiatives, whose sole motivation is to resolve the problem of poor access to better performing markets by smallholder farmers, have thus focused on supporting information transfer through ICT-based innovations (Aker, 2008; Tollens, 2006). These innovations include mobile telephony, internet/web-based means, and interactive video and CD-ROM programs as well as older ICT-based technologies namely the radio and television. The promotion of these mostly new generation ICT tools especially the mobile phones stems from its rapid penetration in Africa and increased ownership by rural population (J. J. Okello, R. M. Okello, \& Ofwona-Adera, 2010).

The growing attention on innovative access to information is anchored on the critical role they can play, namely: i). communicating knowledge and information to smallholder farmers, ii). providing educative and training components to farmers at affordable rates, iii). improving rural producers' access to remunerative markets and farm credit, iv). endowing smallholders to effectively bargain for profitable prices, and v). mobilizing, promoting and enhancing networking among smallholder farmers (Okello, Kirui, Njiraini, \& Gitonga, 2011).

Despite the proliferation of ICT Information Systems, capable of addressing farmers' marketing information needs, numerous challenges still prevail, such as low prices for farm produce and poor access to agricultural inputs, attributed to poor bargaining power. The problem has been blamed to such factors as low literacy among the target users, complexity of some tools, and lack of electricity in the rural areas, and so, the awareness and level of utilization of the services offered by these initiatives among farming communities is reportedly low (Munyua, 2007). Owing to the reality that little is known about the application of these tools for agricultural transactions has further undermined their usage.

This study examines the factors that determine the use of ICT tools for agricultural transactions by assessing the factors that affect mostly these tools, with more emphasis on mobile phones, which is undoubtedly the most popularly owned and adopted new generation ICT tool among farm households, for agricultural purposes. Principally, the study focuses on smallholder farmers in Bungoma County. It uses data collected in 2011 from smallholder farmers stratified by participation in Kenya Agricultural Commodity Exchange, an ICT-based Market Information Service project. The rest of this paper is organized as follows: Section 2 presents the conceptual framework used for study. This is followed by Section 3, which presents and discusses the study results. The conclusion of the study is presented in Section 4.

\section{Methods}

\subsection{Conceptual Framework}

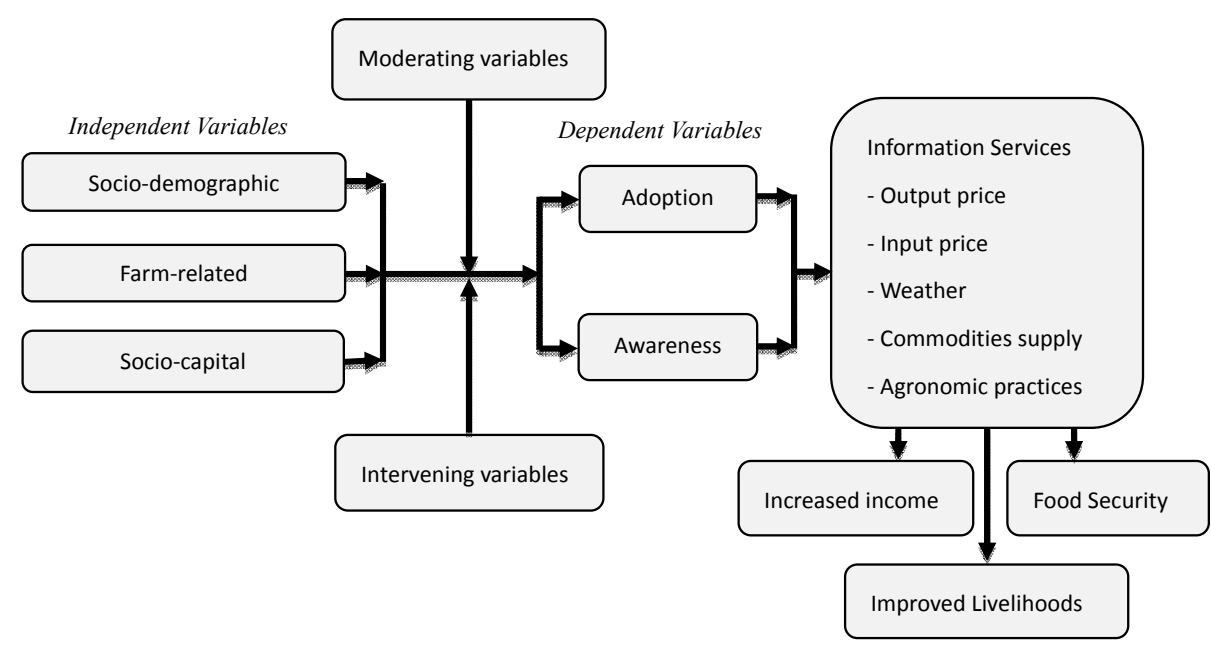

Figure 1. Conceptual Framework on Information access impact on rural livelihoods 
Market information continues to be an increasingly vital variable in production and marketing for small-scale agriculture (Rao, 2007). Timely information facilitated by ICT tools has the potential to fast-track agricultural development by connecting producers to profitable markets. Knowledge about what and when to plant; where and who is buying the farm produce and the price on offer, will enhance the profitability of farming enterprise (Abraham, 2006). In situations where the producer is less informed about the market prices, he is likely to be exploited by the more informed buyer, described by Williamson (1985) as "a self-interest seeking with guile (Williamson, 1985). Accurate information on the costs of inputs, and other costs of production, is critical for decision making by the producer to ensure production efficiency and thus improved profitability (Muto \& Yamano, 2009). As demonstrated by the conceptual framework in Figure 1, awareness and use of ICT tools would enhance farmers access to timely and accurate information, necessary for making informed decisions (Fong, 2009; Muto \& Yamano, 2009; Overå, 2006). However, awareness and use of these ICT tools for agricultural transactions, is conditioned by various variables, as documented in reviewed studies (Aker, 2008; Munyua, 2007; Okello et al., 2011). On the other hand, effective deployment of ICT tools enhance agricultural competitiveness, resulting to increased income, improved livelihoods and food security (Rao, 2007)

\subsection{Empirical Models}

In this section a layout of the empirical methods used in analyzing the determinants of use of ICT tools are presented. Later, factors affecting the use and intensity of use of mobile phones by small farm households for agricultural transactions are examined. Lastly the sampling procedure and data are described.

\subsubsection{Determinants of Use of ICT Tools (Mobile Phones) in Agriculture}

Logistic regression model was used to examine the factors that condition the use of KACE information services. Researchers prefer this model over Probit, because of its powerful comparative mathematical simplicity. In a logistic regression model, the probability, $p$, that a household will use ICT tool for agricultural transaction is given by the reduced form of a logit model below:

$$
P=e^{z} / 1+e^{z}
$$

The significance to using logistic regression is primarily the logit transformation of $p$ given by $Z$

$$
Z=\ln (p / 1-p)
$$

Where,

$$
Z=X \beta+\varepsilon
$$

$\beta$ represents the vector of regression parameters, while $X$ represents the explanatory variables' vector, and $\varepsilon$ represents the stochastic term, which is assumed to have a logistic distribution (Maddala, 1986). For this study, the vector $X$ encompasses demographic characteristics of farmers, physical, capital, social and human endowments. $Z$ represents a latent variable that assumes the value of 1 if the farmer uses KACE ICT services and 0 if otherwise.

\subsubsection{Assessing Intensity of Use of KACE ICT Tools}

Intensity of use of ICT tools in this study refers to the number of tools a farmer used, to access information from Kenya Agricultural Commodity Exchange (KACE). The number of tools a given farmer uses to access information assumes integer values of discrete nature and is therefore a non-negative count variable. According to Maddala (1986), count data are non-normal and hence are not well estimated by Ordinary Least Squares (OLS) regression (Maddala, 1986).

The most preferred models in analyzing count data include the Poisson Regression Model (PRM), the Negative Binomial Regression Model (NBRM), the Zero Inflated Negative Binomial (ZINB) and the Zero Inflated Poisson (ZIP). Some authors have pointed that Poisson and negative binomial regression models are the most popular models for analyzing response variables with nonnegative integer (Greene, 2008; Winkelman \& Zimmerman, 1995). The remaining two models, ZIP and ZINB, are particularly used in accounting for the frequency of zero counts (in cases where more zeros are recorded, than expected, in either PRM or NBRM). However, that is not the scenario in the case of this study. The response variables in this study were nonnegative integers and with not many zero counts. Hence a discussion of PRM and NBRM was undertaken.

Poisson regression is a modeling method that overcomes some of the problems of traditional normal regression in which the errors are assumed to be normally distributed (Cameron \& Trivedi, 1998). The Poisson model analyses is normally the first form of analysis in many count data analyses (Areal et al., 2008). The model rests on assumption that the dependent variable $y$ given vector of predictor variables $x$ has a Poisson distribution. Given $x$, the probability density function of $y$ is completely determined by the conditional mean as presented by 
the $\log$ linear expression 4 and 5 below. PRM specifies that each observation $y_{i}$ is drawn from a Poisson distribution with parameter $\lambda_{i}$ which is related to a ray of predictor variables $X^{\prime}$ (Greene, 2003, 2008). The model is derived from the Poisson distribution by introducing parameters into the relationship between the mean parameter $\lambda_{i}$ and predictor variables $X^{\prime}$.

$$
\begin{gathered}
\lambda(x)=E(y \mid x) \\
f\left(y_{i} \mid x_{i}\right)=\frac{\mathrm{e}^{-\lambda(x)} \lambda_{i}(x)^{y}}{\Gamma\left(1+y_{i}\right)}
\end{gathered}
$$

Where,

$\lambda_{i}=\exp \left(\alpha+X^{\prime} \beta\right)$ and $y_{i}=0,1, \ldots, i$ is the number/count of tools/services used (in our case); $X=$ a vector of predictor variables.

Wooldridge $(2002)$ and Greene $(2003,2008)$ have demonstrated that the expected number of events, $y_{i}$, (in this case, number of tools used for accessing information via KACE ICT tools) is given as below(Greene, 2003, 2008; Woodridge, 2002):

$$
E\left(y_{i} \mid x_{i}\right)=\operatorname{var}\left[y_{i} \mid x_{i}\right]=\lambda_{i}=\exp \left(\alpha+X^{\prime} \beta\right) \text { for } i=1,2, \ldots, \mathrm{n}
$$

The log-linear conditional mean function $e\left(y_{i} \mid x_{i}\right)=\lambda_{i}$ and its equi-dispersion $\operatorname{var}\left(y_{i} \mid x_{i}\right)=\lambda_{i}$ assumptions are the main features of Poisson regression model (Greene, 2003, 2008). As pointed out by Winkelmann and Zimmermann (1995), the log-linear regression models account for the non-negative constraint imposed on the dependent variable by Poisson (Winkelman \& Zimmerman, 1995). The Poisson distribution is often used to model information on counts of numerous kinds, predominantly in situations where the natural "denominator", is missing, implying the absence of limit or upper bound on how big observed counts can be. The Binomial distribution, on the other hand, emphasizes on observed proportions.

\subsection{Sampling Procedure and Data}

This study used data collected from smallholder farmers located in Bungoma South and Bungoma Central sub-counties of Bungoma County. Personal interviews were conducted among a total of 136 respondents. To determine the sample size used for this study, Cochran's (1963) formula was used. For large populations, Cochran developed the following equation:

$$
n_{0}=\frac{Z^{2} p q}{e^{2}}
$$

Where, $n_{0}$ is the sample size, $Z^{2}$ is the abscissa of the normal curve that cuts off an area at the tails (1- equals the desired confidence level, e.g. $95 \%$, e is the desired level of precision, while p represents the proportion estimate of an attribute that is present in the population, and $q$ is $1-p$. The value $\mathrm{Z}$ is found in statistical tables which contains the area under the normal curve (Israel, 1992).

For this study, assuming, $p=.5$ (maximum variability), desired confidence level of $90 \%$ and $\pm 10 \%$ precision:

$$
n_{0}=\frac{\left.(1.96)^{2}(.5) .5\right)}{(.01)^{2}}=96 \text { Farmers }
$$

To compensate for the farmers that may not be possible to reach, a 10 percent was added. Similarly, to compensate for the likely non-responses, it requires a further 30 percent (Vehovar, Batagelj, Manfreda, \& Zaletel, 2002). A total of 136 farmers were hence interviewed during the study.

The target populations for this study were farmers in Bungoma South and Bungoma Central Districts. These two districts are principally the hub of KACE operations, popularly known for technology-driven innovations of linking producers and buyers.

Two divisions were purposively selected from each of the two districts. All the locations in the selected divisions were listed, from which, one was randomly selected. Sub-locations from the chosen locations were listed and one from each randomly picked. Random sampling was used to select two villages from the chosen sub-locations. Using the list of the villages at the selected sub-location, the first and second village was selected from each sub-location based on the distance to the nearest main market. Village one was closer to the market while village 2 was further away from the market. The major reason for this was the observed heterogeneity in socio-economic characteristics of the households across the villages. While households near the market tended to be settled on tiny pieces of land, mostly purchased, their counterparts in villages away from the market were practicing 
farming on ancestral pieces of land. A total of 17 farmers from each of the eight villages were randomly selected and interviewed. This translated to a sample of 136 respondents.

\section{Results and Discussions}

\subsection{Determinants of Use of KACE Information Services}

Farmers' use of ICT tools, was measured using a dichotomous (binary) choice variable of "Yes" or "No" type signifying farmers' use (Yes) or non-use (No) of KACE ICT tools.

Among the variables included in the model were respondents' contact with extension; farmers' perception on service relevance and affordability. Respondents were asked on whether they thought information services offered by KACE were affordable in terms of premiums attached, or otherwise. Table 1 presents the estimates of regression model output to determine the factors that condition the use of ICT tools.

Table 1. Estimation results for the logit regression model on Use of KACE ICT project

\begin{tabular}{|c|c|c|c|c|c|}
\hline \multirow{2}{*}{$\begin{array}{l}\text { Independent variable definition } \\
\text { Variable }\end{array}$} & \multicolumn{3}{|c|}{ Logit regression } & \multicolumn{2}{|c|}{ Marginal effect } \\
\hline & Coefficient & Std. Err. & P-value & Coeff & P-value \\
\hline Gender & 2.2 & 0.65 & 0.000 & 0.23 & $0.000 * * *$ \\
\hline Age & -1.53 & 0.03 & 0.001 & -0.34 & $0.001 * * *$ \\
\hline Education & 1.17 & 0.10 & 0.000 & 0.26 & $0.000 * * *$ \\
\hline Main occupation & 0.6 & 0.93 & 0.876 & 0.74 & 0.875 \\
\hline Family size & -1.14 & 0.10 & 0.599 & -0.82 & 0.599 \\
\hline Farm size & -0.01 & 0.22 & 0.149 & -0.21 & 0.148 \\
\hline Farm ownership & 0.54 & 0.52 & 0.298 & 0.06 & 0.298 \\
\hline Farm income & 0.2 & 0.23 & 0.663 & 0.03 & 0.663 \\
\hline Contact with Extension & 0.05 & 0.94 & 0.104 & 0.005 & $0.094 *$ \\
\hline KACE Importance & 1.48 & 0.56 & 0.376 & 0.463 & $0.037^{*}$ \\
\hline Affordability & 1.32 & 0.65 & 2.030 & 1.08 & $0.045 * *$ \\
\hline Mobile ownership & 0.32 & 0.81 & 0.146 & 0.065 & 0.146 \\
\hline Group membership & 1.48 & 0.56 & 0.009 & 0.236 & $0.008^{*}$ \\
\hline Radio listenership & 0.4 & 19.4 & 0.566 & 0.023 & 0.566 \\
\hline Radio farm program listenership & 1.97 & 0.78 & 0.012 & 0.875 & 0.012 \\
\hline cons & -2.43 & 1.559 & 0.438 & & \\
\hline \multicolumn{6}{|l|}{ Log likelihood $=-47.65$} \\
\hline Pseudo $\mathrm{R}^{2}=0.46 \quad$ LR chi 2 & LR $\operatorname{chi} 2(14)=84.14$ & \multicolumn{2}{|c|}{ Prob $>$ chi $2=0.000$} & & \\
\hline
\end{tabular}

Note. Std. Err. $=$ Standard error, Coeff $=$ Coefficient; Significance at $1 \%, 5 \%$, and $10 \%$ levels is denoted respectively by $* * *, * *, *$.

From the results, gender, age, education and group membership were significant in determining the decision to use ICT tools. Holding all other factors constant, an increase in education level by one year is estimated to increase adoption by 0.26 . Younger and hence more educated farmers are more likely to use ICT tools for seeking market information. Age has an inverse relationship to the likelihood of use of ICT tools. A unit increase in age decreases the likelihood of use of ICT tools by 0.3 , with all other factors held constant. The younger people are more likely than older people to be enthusiastic about new technology and hence more likely to purchase advanced technology. Regarding gender, with the rest of other factors held constant, men are 0.23 times more expected to use KACE ICT tools than women. This could be explained by most cultural practices which assign most of the domestic chores to women, leaving them with almost no extra time to allow them to seek such services. Group membership was also significant to the decision to use ICT services. Belonging to a social group increases the likelihood of using ICT tools by 23.6 percent. As information is disseminated better in farmer groups, members of those groups acquire more knowledge about existing services than non-members. This finding corroborates, Chabossou et al. (2009) study that demonstrated a relationship between mobile adoption and membership of "social networks" (church groups and sports clubs). In their model, they found that 
belonging to such networks contributed positively to the probability of mobile adoption in seven of the seventeen study countries, but not the others (Chabossou, C. Stork, M. Stork, \& Zahonogo, 2009).

The results of the model suggest that increased perception of importance and affordability of the services were also significant to the propensity of farmers to use ICT services, which agrees with the theoretical adoption literature. Perceived usefulness has been considered an important influence in technology adoption (Snowden, Spafford, Michaelides, \& Hopkins, 2006).

However, the respondent's contact with extension workers was not statistically significant, perhaps an indication of a weakening impact of extension on farmer's decision to use the technology. The reason to this could be attributed to the rather erratic contact between extension workers and the farmers. In fact, studies have demonstrated that stagnation in public investment and the breakdown of extension services has widened gaps between the yield from experimental farms and the yield from farmers' fields. Further, deficiency of extension staff and poor access to information has impeded the transfer of technology at the farm level (Mittal, Gandhi, \& Tripathi, 2010).

\subsection{Determinants of Intensity of Use of KACE Information Tools}

To assess the factors determining the extent to which smallholder farmers use KACE information tools, the study used Poisson regression techniques. This count variable model was chosen because of its suitability for dependent variables that are countable finite such as the number of times a farmer uses a service (Gitonga, 2009). Results for the Poisson regression model are presented in Table 2.

Table 2. Poisson model of the intensity of the use of KACE ICT tools by farmers

\begin{tabular}{|c|c|c|}
\hline \multirow{2}{*}{$\begin{array}{l}\text { Independent Variables } \\
\text { Unit }\end{array}$} & \multicolumn{2}{|c|}{ Poisson regression } \\
\hline & Coef. & P-value \\
\hline Gender & 0.75 & $0.001 * * *$ \\
\hline Age & -1.53 & $0.012 * *$ \\
\hline Education & 1.21 & $0.005 * * *$ \\
\hline Main occupation & 0.64 & 0.181 \\
\hline Family size & -0.14 & 0.432 \\
\hline Farm size & -0.01 & 0.149 \\
\hline Farm ownership & 0.45 & 0.145 \\
\hline Farm income & 0.09 & 0.129 \\
\hline Contact with Extension & 0.05 & 0.163 \\
\hline KACE Importance & 1.68 & $0.003 * * *$ \\
\hline Affordability & 1.32 & $0.005^{* * *}$ \\
\hline Mobile ownership & 1.32 & $0.004 * * *$ \\
\hline Group membership & 1.48 & $0.008 * * *$ \\
\hline Radio listenership & 0.4 & 0.14 \\
\hline Radio farm program listenership & 1.79 & $0.078^{*}$ \\
\hline Distance to the nearest center that has electricity $(\mathrm{km})$ & -0.006 & $0.069^{*}$ \\
\hline Distance the produce and livestock market $(\mathrm{km})$ & 0.37 & $0.067 *$ \\
\hline cons & -2.43 & 19.6 \\
\hline \multicolumn{3}{|l|}{ Log likelihood $=-57.25$} \\
\hline \multicolumn{3}{|l|}{ Psedo $\mathrm{R}^{2}=0.26$} \\
\hline LR chi2 $(14)=89.14 \quad$ Prob $>$ chi $^{2}=0.000$ & & \\
\hline Number of observations $=136$ & & \\
\hline
\end{tabular}

Note. Significance at $1 \%, 5 \%$, and $10 \%$ levels is denoted respectively by $* * *, * *, *$.

The results estimate that among the farmer-specific variables, gender and age, influence the intensity of use of KACE ICT tools. Men are likely to use more tools, including make more calls by more than 0.75 times than their female counterparts, ceteris paribus. This could be attributed to the fact that men are the controllers of the financial enterprises in most of the rural households. This finding corroborates earlier research which argued that 
culture among rural farmers which entrusts the responsibilities of purchasing inputs and planning for output sale on men, affects the use of ICT tools such as mobile phones (Mittal et al., 2010; Okello et al., 2011).

Increase in age of the respondent by one year reduces the expected number of KACE ICT tools used by 27 percent. The inverse relationship between age and use of KACE ICT to access market information, which upholds the findings by past studies, suggest that this group of farmers are more literate and well equipped to use ICT tools (Okello et al., 2011). Being a member of a farmers group is also expected to have a positive effect on use of KACE information services.

There was no demonstrated relationship, between the extent of use of ICT tools and distance to the nearest market connected with electricity between distance; and to the main produce market. However, past studies suggest an inverse relationship between distance to the market and number of mobile phone calls by farmers for agricultural transaction purposes (Okello et al., 2011). The difference in the results could be attributed to the fact that the previous studies focused on a single ICT tool, such as number of voice calls or messages, in evaluating intensity. On the other hand, this study was based on different ICT tools, some of which were to be accessed at KACE's merchandize shops, such as displayed commodity prices, while other services such as farm radio programs, including Soko Hewani (Supermarket on air), a service that could be accessed on a household radio. More than 84 percent of the households in the surveyed area own at least one radio set (Wawire, 2013).

Similarly, Group membership, perceived importance, affordability and mobile ownership were significant to the extent of use of ICT tools in accessing information. A farmer belonging to a group is likely to gain from formal trainings and sensitization programs, thus exposing him to numerous technologies. A technology perceived to have greater returns is likely to motivate farmers in using it, with expectations of maximizing returns. The cost of technology influences its adoption. Farmers will shy away from technologies that are perceived to be too costly. A study on Gherkin farmers in Sri Lanka by De Silva and Ratnadiwakara (2008) also found that farmers are willing to pay for such services if it would save their time and money (De Silva \& Ratnadiwakara, 2008).

Among capital endowment variables, education, literacy and mobile ownership, condition the extent of using ICT tools. Farmers with more years of education are likely to use more tools, ranging from the simple ICT tools to the most sophisticated ICT tools, to access market information than their illiterate counterparts. One unit increase in education is expected to increases the expected number of KACE ICT tools used by 0.32. Literacy plays a big role in technology adoption, as the use of some of these tools require some technological-know-how. The findings support arguments of Davis (1989) and Davis, Bagozzi, and Warshaw (1989) on the Theory of Acceptance model (Davis, 1989; Davis, Bagozzi, \& Warshaw, 1989). Mobile ownership increases the likelihood of intensifying access to information. Although some researches have argued that farmers use mobile phones for mostly non-agricultural transactions, such as money transfer (Kirui, Okello, \& Nyikal, 2010).

\section{Summary, Conclusions and Recommendations}

The study examines the use of KACE information tools and services among the smallholder farmers in Bungoma County of Kenya. It uses a Logit regression model to examine the factors conditioning use of ICT tools and a Poisson regression model to assess the conditioners of intensity of use of ICT tools for agricultural transactions. Whereas mobile phone ownership was not significant to a decision to use ICT tools, it influenced the intensity of use of the ICT tools.

The study further finds that age, literacy level, gender, perceived importance, affordability and group membership, significantly influence the decision to use ICT, as well as the intensity of use of such tools. Young and educated farmers, considered more educated, are more outgoing and willing to know what is going on in their environment as compared to their older counterparts, otherwise viewed as conservatives stuck in the past (Aker, 2008). More men compared to women have an opportunity to interact with the outside world and therefore more placed to be aware of the technology in the market. This is because of the culture, which allocates women to non-financial responsibilities, while leaving financial obligations (which may require seeking of information) to men (Sen, 1999). Women empowerment is therefore necessary in effort to improve production and enhance the living conditions of the rural population (Fonjong, Fombe, \& Sama-Lang, 2013; Okello et al., 2010).

The implication of the findings of this study is that there is need to sensitize smallholder farmers on the KACE information services and other ICT-based market information platforms. Application of ICT in agriculture presents a potential opportunity of resolving the asymmetry in market information responsible for market failures (Cullen, 2003; Dey et al., 2008; Rogaly et al., 1999). Further, there is need to support the emerging ICT applications, while ensuring an enabling environment and infrastructures, such as electricity. This is a major constraint in most rural homes, where one must trek quite a long distance to charge their mobile phones 
(Furuholt \& Matotay, 2011). The findings of this study identify priorities for policymakers and other stakeholders, including the private sector to invest in projects that aim at linking farmers to market and other agricultural information. Efforts should also be made to empower the farmers with knowledge on how to use the facilities; since most of the farmers are either illiterate or semi-illiterate. Increased investment in education to improve its quality is therefore key to boosting adoption of new technologies. Education should also be further extended to organized farmers' groups to increase their uptake of the new technologies. Farmers' organization groups (collective action), which have been found to play a significant role in technology adoption, should be a key priority area (Lee, 2005). The groups should also be supported to ensure their sustainable operations.

It has been observed that age is likely to be a hindrance in technology adoption, with young people being more likely than older people to embrace new ways of doing things. Adoption models have shown that ease of use influences acceptance of technology (Snowden et al., 2006) There is need to design technologies that takes care of the interest of the older people. This group constitutes a significant number of the users of commercial services. Understanding and addressing these needs of this group will present a major market opportunity for new ICT products and services.

Policy on its own, however, cannot guarantee access to and use of ICTs in these areas. Motivational and educational strategies aimed at overcoming resistance, demonstrating the usefulness of the technologies and developing digital skills and content are necessary (Snowden et al., 2006). Extensive experience shows that facilitating farmers' access to ICTs can be realized through telecentres and computer-supply and connectivity programmes for rural schools.

\section{Acknowledgements}

I am highly indebted to the Kenya National Council for Science and Technology for funding this research. There are not enough words to describe the council's excellent work of providing grants for research at all levels. You are truly the heart and soul of research and innovations in this country.

This work is a product of collaborative efforts from numerous people of good will. First and foremost, I wish to register my sincerest gratitude to my academic mentors: Dr Sabina Wangia and Dr. Julius Okello for their abundant help and their inexhaustible suggestions. I attribute this work to their encouragement and effort and without which, execution of this research would not have been possible.

Much gratitude to the following people for having contributed to the success of this work in one way or the other: Ms. Beatrice Wafula, office of the District commissioner, Bungoma South district for providing me with the current Geographical map of the area. Thanks to Mr. Kirui Stanley, the District Agricultural Officer (DAO), Bungoma Central and Adelaide Waswa, the Divisional Agricultural Extension Officer (DAEO), Chwele Division for their assistance during the field survey. My Special thanks go to Kenya Agricultural Commodity Exchange (KACE), staff; Pius Wamalwa, and Alex Wasari.

\section{References}

Abraham, R. (2006). Mobile phones and economic development: Evidence from the fishing industry in India. Paper presented at the 2006 International Conference on Information and Communication Technologies and Development. http://dx.doi.org/10.1109/ictd.2006.301837

Aker, J. C. (2008). Does digital divide or provide? The impact of cell phones on grain markets in Niger (p. 154). Center for Global Development Working Paper.

Areal, F., Touza, J., MacLeod, A., Dehnen-Schmutz, K., Perrings, C., Palmieri, M., \& Spence, N. (2008). Integrating drivers influencing the detection of plant pests carried in the international cut flower trade. Journal of Environmental Management, 89(4), 300-307. http://dx.doi.org/10.1016/j.jenvunam.2007.06.017

Cameron, C., \& Trivedi, P. (1998). Models for Count Data. Cambridge University Press, Cambridge. http://dx.doi.org/10.1002/sim.768

Chabossou, A., Stork, C., Stork, M., \& Zahonogo, Z. (2009). Mobile telephony access and usage in Africa. Paper presented at the Information and Communication Technologies and Development (ICTD), 2009 Proceedings of the Third International Conference on Information and Communication Technologies and Development, Carnegie Mellon Qatar, Doha, Qatar, April 17-19, 2009.

Cullen, R. (2003). The digital divide: A global and national call to action. The Electronic Library, 21(3), 247-257. http://dx.doi.org/10.1108/02640470310480506

Davis, F. D. (1989). Perceived usefulness, perceived ease of use, and user acceptance of information technology. MIS Quarterly, 319-340. http://dx.doi.org/10.2307/249008 
Davis, F. D., Bagozzi, R. P., \& Warshaw, P. R. (1989). User acceptance of computer technology: A comparison of two theoretical models. Management Science, 35(8), 982-1003. http://dx.doi.org/10.1287/mnsc.35.8.982

De Silva, H., \& Ratnadiwakara, D. (2008). Using ICT to reduce transaction costs in agriculture through better communication: A case-study from Sri Lanka. LIRNEasia, Colombo, Sri Lanka.

Dey, B. L., Prendergast, R., \& Newman, D. (2008). How can ICTs be used and appropriated to address agricultural information needs of Bangladeshi farmers? GlobDev, 21. Retrieved from http://aisel.aisnet.org/ globdev2008/21

Ferris, S., Engoru, P., \& Kaganzi, E. (2008). Making market information services work better for the poor in Uganda. CGIAR Systemwide Program on Collective Action and Property Rights, International Food Policy Research Institute. http://dx.doi.org/10.2499/capriwp77

Fong, M. W. (2009). Digital divide between urban and rural regions in China. The Electronic Journal of Information Systems in Developing Countries, 36.

Fonjong, L., Fombe, L., \& Sama-Lang, I. (2013). The paradox of gender discrimination in land ownership and women's contribution to poverty reduction in Anglophone Cameroon. GeoJournal, 78(3), 575-589. http://dx.doi.org/10.1007/s10708-012-9452-z

Furuholt, B., \& Matotay, E. (2011). The developmental contribution from mobile phones across the agricultural value chain in rural Africa. The Electronic Journal of Information Systems in Developing Countries, 48.

Gitonga, Z. (2009). Economic assessment of leafminer invasion and control strategies in Kenya's snowpea industry: The case of Nyeri North and South Imenti Districts.

Greene, H. W. (2008). Functional forms for the negative binomial model for count data. Economics Letters, 99(3), 585-590. http://dx.doi.org/10.1016/j.econlet.2007.10.015

Greene, W. H. (2003). Econometric analysis. Pearson Education Pearson Education Inc, New York University.

Israel, G. D. (1992). Determining sample size. University of Florida Cooperative Extension Service, Institute of Food and Agriculture Sciences, EDIS.

Kirui, O. K., Okello, J. J., \& Nyikal, R. A. (2010). Awareness and use of m-banking services in agriculture: The case of smallholder farmers in Kenya. Paper presented at the 2010 AAAE Third Conference/AEASA 48th Conference. http://dx.doi.org/10.4018/jictrda.2012010101

Lee, D. R. (2005). Agricultural sustainability and technology adoption: Issues and policies for developing countries. American Journal of Agricultural Economics, 87(5), 1325-1334. http://dx.doi.org/10.1111/ j.1467-8276.2005.00826.x

Maddala, G. S. (1986). Limited-dependent and qualitative variables in econometrics. Cambridge university Press.

Mittal, S., Gandhi, S., \& Tripathi, G. (2010). Socio-economic impact of mobile phones on Indian agriculture. Indian Council for Research on International Economic Relations New Delhi.

Munyua, H. (2007). ICTs and small-scale agriculture in Africa: A scoping study. Unpublished Report 1, Submitted to International Development Research Center.

Muto, M., \& Yamano, T. (2009). The impact of mobile phone coverage expansion on market participation: Panel data evidence from Uganda. World Development, 37(12), 1887-1896. http://dx.doi.org/10.1016/j.worlddev. 2009.05.004

Okello, J. J., Kirui, O., Njiraini, G. W., \& Gitonga, Z. (2011). Drivers of use of information and communication technologies by farm households: The case of smallholder farmers in Kenya. Journal of Agricultural Science, 4(2), 111. http://dx.doi.org/10.5539/jas.v4n2p111

Okello, J. J., Okello, R. M., \& Ofwona-Adera, E. (2010). Awareness and the use of mobile phones for market linkage by smallholder farmers in Kenya. http://dx.doi.org/10.4018/978-1-60566-820-8.ch001

Overå, R. (2006). Networks, distance, and trust: Telecommunications development and changing trading practices in Ghana. World Development, 34(7), 1301-1315. http://dx.doi.org/10.1016/j.worlddev.2005. 11.015

Rao, N. (2007). A framework for implementing information and communication technologies in agricultural development in India. Technological Forecasting and Social Change, 74(4), 491-518. http://dx.doi.org/ 10.1016/j.techfore.2006.02.002 
Rogaly, B., Harriss-White, B., \& Bose, S. (1999). Introduction: Agricultural growth and agrarian change in West Bengal and Bangladesh. In Rogaly et al. (Ed.), Sonar Bangla? Agricultural Growth and Agrarian Change in West Bengal and Bangladesh. New Delhi, Sage Publications. http://dx.doi.org/10.1177/006996670 103500208

Sen, P. (1999). Enhancing women's choices in responding to domestic violence in Calcutta: A comparison of employment and education. The European Journal of Development Research, 11(2), 65-86. https://doi.org/10.1080/09578819908426739

Snowden, S., Spafford, J., Michaelides, R., \& Hopkins, J. (2006). Technology acceptance and m-commerce in an operational environment. Journal of Enterprise Information Management, 19(5), 525-539. http://dx.doi.org/ $10.1108 / 17410390610703657$

Tollens, E. F. (2006). Market information systems in sub-Sahara Africa challenges and opportunities. Paper presented at the The Intl. Assoc. of Agri. Economists Conference, Australia.

Vehovar, V., Batagelj, Z., Manfreda, K. L., \& Zaletel, M. (2002). Nonresponse in web surveys. Survey Nonresponse, 229-242.

Wawire, A. W. (2013). Awareness and Use of Kenya Agricultural Commodity Exchange Services (Kace) Information Services by Smallholder Farmers of Bungoma County, Kenya. University of Nairobi.

Williamson, O. E. (1985). The economic institutions of capitalism: Firms, markets, relational contracting. New York, 61-75. http://dx.doi.org/10.1007/978-3-8349-9320-5_6

Winkelman, R., \& Zimmerman, K. F. (1995). Recent developments in count data modelling: Theory and applications. Journal of Economic Surveys, 9(1), 1-23. http://dx.doi.org/10.1111/j.1467-6419.1995.tb 00108.x

Woodridge, J. (2002). Econometric analysis of cross sectional data and panel data. Cambridge and London: MIT Press.

\section{Copyrights}

Copyright for this article is retained by the author(s), with first publication rights granted to the journal.

This is an open-access article distributed under the terms and conditions of the Creative Commons Attribution license (http://creativecommons.org/licenses/by/4.0/). 